\title{
Genome-wide scan identifies novel modifier loci of acromegalic phenotypes for isolated familial somatotropinoma
}

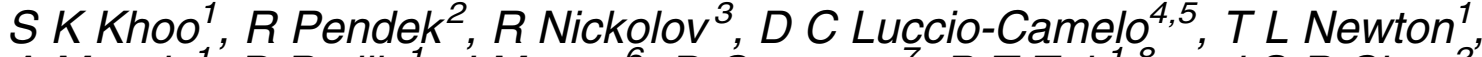

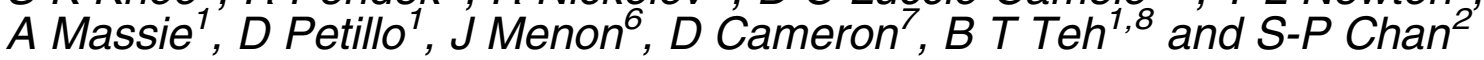 \\ ${ }^{1}$ Laboratory of Cancer Genetics, Van Andel Research Institute, Grand Rapids, Michigan 49503, USA \\ ${ }^{2}$ Department of Medicine, University of Malaya Medical Centre, 50603 Kuala Lumpur, Malaysia \\ ${ }^{3}$ Department of Mathematics and Computer Science, Fayetteville State University, Fayetteville, North Carolina 28301, USA \\ ${ }^{4}$ Serviço de Endocrinologia, Hospital Universitário Clementino Fraga Filho, UFRJ, Rio de Janeiro 21949-590, Brazil \\ ${ }^{5}$ Department of Urology, University of Illinois at Chicago, Chicago, Illinois 60612, USA \\ ${ }^{6}$ Department of Medicine, Queen Elizabeth Hospital, 88586 Kota Kinabalu, Sabah, Malaysia \\ ${ }^{7}$ Department of Diabetes and Endocrinology, Princess Alexandra Hospital, Brisbane, Queensland 4102, Australia \\ ${ }^{8}$ NCCS-VARI Translational Cancer Research Laboratory, National Cancer Centre, Singapore, Republic of Singapore 169610 \\ (Correspondence should be addressed to S K Khoo; Email: sok-kean.khoo@vai.org; S-P Chan; Email: spchan88@ hotmail.com)
}

\begin{abstract}
Isolated familial somatotropinoma (IFS) accounts for $18 \%$ of familial isolated pituitary adenoma (FIPA) cases. Recently, germline mutations of the aryl hydrocarbon receptor-interacting protein gene $(A I P)$ have been found in families with pituitary adenoma predisposition, FIPA, and IFS. In this study, we investigate the AIP mutation status and perform a genome-wide scan to search for the modifier regions of acromegalic phenotypes in an IFS family of 31 aborigines from Borneo. Complete endocrine diagnosis and data could not be collected due to logistical and cultural reasons. AIP mutation screening was carried out by direct sequencing and the genomewide scan was performed using 400 microsatellites. Non-parametric linkage analysis was performed to obtain the logarithm of odds (LOD) scores. A novel AIP frameshift mutation in exon 4 (c.500delC) (p.P167HfsX3) was identified in all members with acromegalic features, as well as in 15 members without acromegalic features, revealing incomplete penetrance of $A I P$. The data showed that patients with the same mutation may express acromegalic features of differing severity, suggesting the existence of modifier genes. The highest LOD score of 2.2 was obtained near D19S571 (19q13.41). We also found weak linkages on chromosomes 3q28, $8 q 12.1$, and $21 q 22.13$, with LOD scores of $1.1,1.8$, and 1.4 respectively. Our results show the first genome-wide scan that identifies novel modifier loci for acromegalic phenotypes in an IFS family. Identification of modifier loci may provide further insight into the disease mechanism and explain the clinical variability observed in its patients.
\end{abstract}

Endocrine-Related Cancer (2009) 16 1057-1063

\section{Introduction}

The prevalence of GH-secreting pituitary adenomas is $\sim 1$ in 1000 (Daly et al. 2006b), although biochemical evidence of acromegaly in previously undiagnosed subjects can occur even more frequently (Schneider et al. 2008). Although these adenomas are not classified as malignant, their excessive production of hormones can cause severe clinical conditions such as obesity and disfigurement, hypertension, diabetes mellitus, and accelerated heart disease. Thus, patients are often faced with an array of debilitating symptoms and difficult treatments.

Familial GH-secreting pituitary adenoma (also known as familial somatotropinoma or familial acromegaly) is a rare clinical entity. Its occurrence is associated with three separate clinical syndromes: multiple endocrine neoplasia type 1 (MEN1); Carney complex; and isolated familial somatotropinoma (IFS). The MENI gene and the protein kinase A regulatory subunit 1 (PRKARlA) gene have been identified as 
genes related to MEN1 and Carney complex respectively (Chandrasekharappa et al. 1997, Kirschner et al. 2000). IFS is defined as the occurrence of at least two cases of acromegaly or gigantism in a family not exhibiting MEN1 or Carney complex. Recently, IFS has been included in the clinical syndrome of familial isolated pituitary adenomas (FIPA) and accounts for $\sim 18 \%$ of FIPA cases (Daly et al. 2006a). Till date, there are $\sim 50$ families with 120 affected members reported with IFS (Beckers \& Daly 2007) and 99 families with 223 affected members reported with FIPA (Daly et al. 2007, Leontiou et al. 2008).

Recently, germline mutations in the aryl hydrocarbon receptor-interacting protein $(A I P)$ gene have been identified in individuals with pituitary adenoma predisposition (PAP; Vierimaa et al. 2006). Since then, a few reports of $A I P$ mutations in both familial and sporadic acromegaly have been published (Barlier et al. 2007, Daly et al. 2007, Iwata et al. 2007, Toledo et al. 2007, Leontiou et al. 2008). Low penetrance of AIP in reported PAP and FIPA families suggests the existence of additional modifier genes. Patients with AIP mutations may or may not present with pituitary adenomas, besides presenting with acromegalic features of differing severity. Since the development of acromegalic phenotypes is insidious, it is important to find the associated genes so that patients can be treated promptly. Here, we performed direct sequencing on all 31 individuals in a large IFS family from Borneo to screen for AIP mutations. Subsequently, to identify the modifier regions based on acromegalic features in IFS, we performed a genome-wide scan using 400 microsatellite markers on the same family.

\section{Materials and methods}

\section{Subjects}

One previously unreported IFS family with 31 members was located in Borneo, Malaysia. The pedigree is shown in Fig. 1. All participating subjects provided informed consent and this study was approved by the Institutional Review Board of the Van Andel Research Institute and the University of Malaya. The studied subjects are the aborigines who live in the mountainous area of Borneo with minimal access to civilization. Our medical group traveled to the village in order to collect the samples. Owing to logistical reasons, the subjects refused to travel to the regional hospital for magnetic resonance imaging (MRI). Blood samples were collected, and the GH levels and insulin-like growth factor-1 (IGF-1) levels were measured from serum. Genomic DNA was obtained from blood using a QIAamp DNA Blood Maxi Kit (Qiagen).

\section{AIP mutation screening}

All six coding exons of $A I P$ were sequenced. The exonspecific primer sequences were designed according to Vierimaa et al. (2006), except those of exon 1 (AIP-SK-1 - forward primer: 5'-AAGCAAGTCCGGAAGCTA-3'; reverse primer: 5'-GTCGAGTTCTGCATGTGAG- $3^{\prime}$ ). PCR condition for exon 1 was performed with $0.4 \%$ dimethyl sulfoxide (DMSO), $0.4 \mu \mathrm{M}$ of each primer, $1.5 \mathrm{mM} \mathrm{MgCl}_{2}, 0.04 \mathrm{mM}$ dNTPs, and 0.2 U Taq DNA polymerase (Invitrogen) with cycling conditions as follows: $95^{\circ} \mathrm{C}$ for $10 \mathrm{~min}$, followed by 35 cycles of $95{ }^{\circ} \mathrm{C}$ for $45 \mathrm{~s} ; 57^{\circ} \mathrm{C}$ for $45 \mathrm{~s}$; $72{ }^{\circ} \mathrm{C}$ for $45 \mathrm{~s}$; and a final extension at $72{ }^{\circ} \mathrm{C}$ for $7 \mathrm{~min}$.

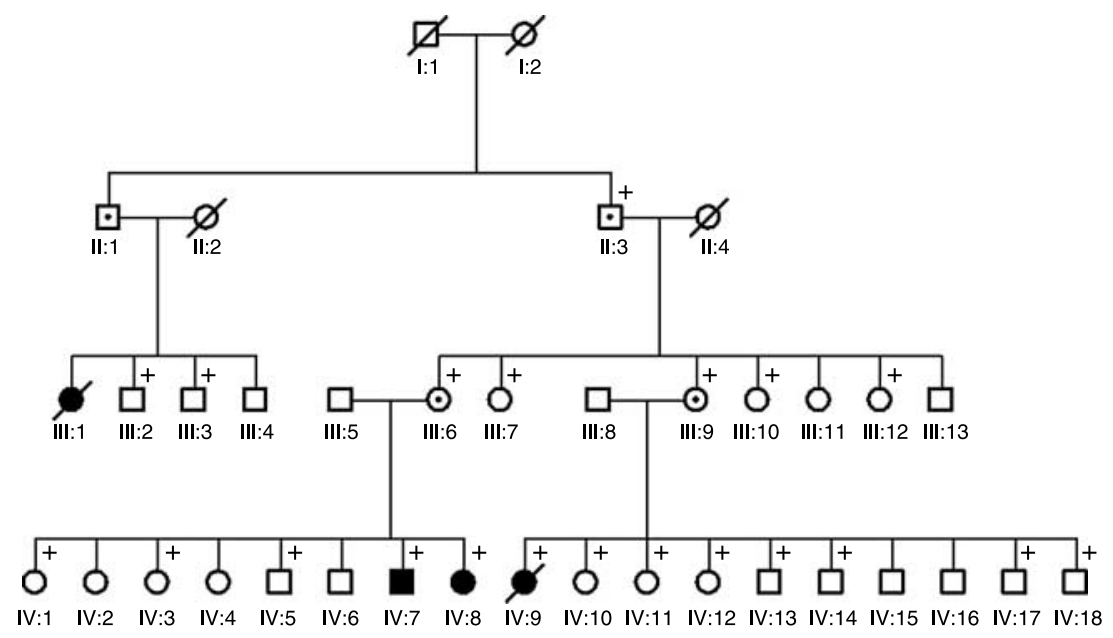

Figure 1 Pedigree of a large Borneo family with IFS, showing incomplete penetrance of $A I P$. Affected and unaffected individuals are shown by filled and open symbols respectively. Suspected carriers are indicated by a dot in the square or circle and deceased individuals are identified by a slash (/). Subjects with AIP mutation are marked by + . 
PCR conditions for exons 2-6 were $1 \mu \mathrm{M}$ of each primer, $1.5 \mathrm{mM} \mathrm{MgCl} 2,0.2 \mathrm{mM} \mathrm{dNTPs}$, and $0.25 \mathrm{U}$ FastStart Taq DNA polymerase (Roche Applied Science). The cycling conditions for exons 2-6 were as follows: $95{ }^{\circ} \mathrm{C}$ for $10 \mathrm{~min}$, followed by 30 cycles of $95^{\circ} \mathrm{C}$ for $30 \mathrm{~s} ; 68{ }^{\circ} \mathrm{C}$ for $20 \mathrm{~s} ; 72{ }^{\circ} \mathrm{C}$ for $30 \mathrm{~s}$; and a final extension at $72{ }^{\circ} \mathrm{C}$ for $7 \mathrm{~min}$. All amplifications were carried out with $25 \mathrm{ng}$ of genomic DNA in a total volume of $25 \mu \mathrm{l}$, and PCR was performed using a MJ Research Tetrad Thermal Cycler (Bio-Rad Laboratories). Amplicons were analyzed on 1.5\% agarose gels before purification using Multiscreen PCR cleanup plates (Millipore, Billerica, MA, USA). Sequencing was performed using Big Dye Terminator (Applied Biosystems, Foster City, CA, USA) and run on an ABI 3700 genetic analyzer (Applied Biosystems). The AIP sequence was obtained from Ensembl (http://www. ensembl.org/index.html) and was aligned with Emboss pairwise alignment algorithms (http://www.ebi.ac.uk/ emboss/align/index.html), as well as being manually verified. All sequence alterations were verified by reamplification of the corresponding AIP exon and repeating the sequencing procedure with both forward and reverse primers.

\section{Genome-wide scanning}

The genomic DNA of 31 individuals from the IFS family was included in a $10 \mathrm{cM}$ density genome-wide scan by using 400 fluorescence-labeled microsatellite markers from the ABI PRISM Human Linkage Mapping Set v. 2 (Applied Biosystems). PCR was performed in a $7.5 \mu \mathrm{l}$ reaction, and its volume containing $0.17 \mu \mathrm{M}$ each of fluorescence-labeled forward and unlabeled reverse primer, $10 \mathrm{mM}$ Tris- $\mathrm{HCl}$ (pH 8.3), $50 \mathrm{mM} \mathrm{KCl,} 4 \mathrm{mM} \mathrm{MgCl}_{2}, 0.3 \mathrm{U}$ AmpliTaq Gold polymerase (Applied Biosystems), $0.25 \mathrm{mM}$ dNTPs (Invitrogen), and $15 \mathrm{ng}$ genomic DNA. PCR was performed using a DNA Engine Tetrad (Bio-Rad Laboratories) with an initial set of 10 cycles $\left(15 \mathrm{~s}\right.$ at $94{ }^{\circ} \mathrm{C}, 15 \mathrm{~s}$ at $55^{\circ} \mathrm{C}, 30 \mathrm{~s}$ at $72{ }^{\circ} \mathrm{C}$ ) followed by 20 cycles $\left(15 \mathrm{~s}\right.$ at $89^{\circ} \mathrm{C}, 15 \mathrm{~s}$ at $55^{\circ} \mathrm{C}, 30 \mathrm{~s}$ at $72{ }^{\circ} \mathrm{C}$ ). All PCR-amplified products were then denatured and run on an ABI 3700 genetic analyzer (Applied Biosystems). Allele sizes were assigned using Genescan v. 3.1 and Genotyper v. 2.5 software Applied Biosystems). Genotypes inconsistent with Mendelian laws were detected using the PedCheck program (O'Connell \& Weeks 1998). Erroneous genotypes were re-examined manually and corrected, or the samples were rerun to confirm the allele calls. Pedigrees and haplotypes were drawn using Cyrillic v. 2.1 (Exeter Software, Setauket, NY, USA).

\section{Linkage analysis}

The biochemical data did not show any clear-cut clinical sign of acromegaly in the subjects (same phenomenon reported by Schneider et al). Therefore, we could not use this set of biochemical data to define the affected subjects for linkage study. On the other hand, since IFS has a much younger age at onset compared with sporadic acromegaly (Soares \& Frohman 2004, Beckers \& Daly 2007). We can assume that subjects $>20$ years old should have their acromegalic features defined. Thus, without MRI data or clearly defined biochemical data, to identify the affected subjects, and until a better diagnosis of acromegaly is defined, it is rational to use the presence or absence of acromegalic features in the AIP mutants and perform linkage analysis to identify the modifier genes related to this phenotype. AIP mutants with acromegalic features are considered as affected (II:3, III:6, III:9, IV:7, IV:8, and IV:9) and AIP mutants without acromegalic features or asymptomatic carriers are non-affected (III:2, III:3, III:7, III:10, III:12, IV:1, IV:3, IV:5, IV:10, IV:13, and IV:14). Teenaged AIP mutants (IV:11, IV:12, IV:17, and IV:18) are considered as unknown. The rest are considered as non-informative. We used a non-parametric approach based on identical-by-descent allele sharing among affected individuals. Calculation of multipoint nonparametric linkage statistics (NPL scores) was carried out using GENEHUNTER beta v. 2.1_R2 (Kruglyak et al. 1996, Kruglyak \& Lander 1998). NPL scores were then converted to LOD scores (Kong \& Cox 1997). Owing to the large number of family members, the data was divided into three separated branches for linkage analysis. The LOD plot was created with the R software package (www.R-project.org).

\section{Results}

The clinical features of the studied subjects are summarized in Table 1. Since the subjects are aborigines from a remote area, they do not have accurate birth records and/or do not know their exact age. Therefore, their ages are given as estimates in decades. Three individuals have prominent acromegalic features (protruding lower jaws and brows, and enlarged hands and feet; IV:7, IV:8, and IV:9), while another three individuals have mild acromegalic features (enlarged hands and feet only; II:3, III:6, and III.9). The rest of the members do not exhibit any acromegalic features. There has not been any new incidence of acromegaly reported in this family since the last collection of data, which was 6 years ago. 
Table 1 Clinical data of members in the Borneo family with isolated familial somatotropinomas

\begin{tabular}{|c|c|c|c|c|c|c|c|}
\hline \multirow[b]{2}{*}{ Subjects } & \multirow[b]{2}{*}{$\begin{array}{l}\text { Age at } \\
\text { diagnosis }\end{array}$} & \multirow[b]{2}{*}{ Sex } & \multirow[b]{2}{*}{$\begin{array}{l}\text { Height } \\
\text { (cm) }\end{array}$} & \multirow[b]{2}{*}{$\begin{array}{l}\text { Acromegalic } \\
\text { features }\end{array}$} & \multirow[b]{2}{*}{$\begin{array}{l}\text { AIP } \\
\text { mutation }\end{array}$} & \multicolumn{2}{|c|}{ Laboratory results } \\
\hline & & & & & & $\begin{array}{l}\text { GH } \\
(\mathrm{mlU} / \mathrm{l})\end{array}$ & $\begin{array}{l}\text { IGF-1 } \\
(\mu \mathrm{g} / \mathrm{I})\end{array}$ \\
\hline II:3 & $90 s$ & M & 160 & Yes & Yes & $<0.5$ & 143.3 \\
\hline III:2 & $50 \mathrm{~s}$ & M & 163 & No & Yes & $<0.5$ & 130.0 \\
\hline III:3 & $50 \mathrm{~s}$ & $M$ & 162 & No & Yes & $<0.5$ & 205.0 \\
\hline III:4 & $50 \mathrm{~s}$ & $M$ & $\mathrm{~N} / \mathrm{D}$ & No & No & $\mathrm{N} / \mathrm{D}$ & N/D \\
\hline III:5 & $60 s$ & M & $\mathrm{N} / \mathrm{D}$ & No & No & $<0.5$ & 174.2 \\
\hline III:6 & $60 \mathrm{~s}$ & $\mathrm{~F}$ & 170 & Yes & Yes & $<0.5$ & 102.6 \\
\hline III:7 & $60 \mathrm{~s}$ & $\mathrm{~F}$ & 167 & No & Yes & $<0.5$ & 163.3 \\
\hline III:9 & $50 \mathrm{~s}$ & $\mathrm{~F}$ & 168 & Yes & Yes & $<0.5$ & 216.2 \\
\hline III:10 & $50 \mathrm{~s}$ & $\mathrm{~F}$ & 165 & No & Yes & 4.1 & 191.3 \\
\hline III:11 & $50 \mathrm{~s}$ & $\mathrm{~F}$ & 162 & No & No & $<0.5$ & 200.0 \\
\hline III:12 & $50 \mathrm{~s}$ & $\mathrm{~F}$ & 163 & No & Yes & 4.8 & 113.4 \\
\hline III:13 & $50 \mathrm{~s}$ & $M$ & 162 & No & No & $<0.5$ & 224.6 \\
\hline IV:1 & $20 \mathrm{~s}$ & $\mathrm{~F}$ & N/D & No & Yes & $<0.5$ & 312.9 \\
\hline IV:2 & $20 \mathrm{~s}$ & $F$ & 165 & No & No & $<0.5$ & 84.7 \\
\hline$I V: 3$ & $20 \mathrm{~s}$ & $\mathrm{~F}$ & 168 & No & Yes & $<0.5$ & 151.3 \\
\hline IV:4 & $20 \mathrm{~s}$ & $\mathrm{~F}$ & 166 & No & No & $<0.5$ & 219.0 \\
\hline IV:5 & $20 \mathrm{~s}$ & $M$ & 171 & No & Yes & $<0.5$ & 236.1 \\
\hline IV:6 & $20 \mathrm{~s}$ & $M$ & $\mathrm{~N} / \mathrm{D}$ & No & No & $<0.5$ & 457.8 \\
\hline IV:7 & $30 \mathrm{~s}$ & $M$ & 175 & Yes & Yes & $\mathrm{N} / \mathrm{D}$ & N/D \\
\hline IV:8 & $30 \mathrm{~s}$ & $F$ & 170 & Yes & Yes & $<0.5$ & 59.8 \\
\hline IV:9 & $20 \mathrm{~s}$ & $\mathrm{~F}$ & 182 & Yes & Yes & 124.2 & 577.5 \\
\hline IV:10 & $20 s$ & $F$ & 169 & No & Yes & 1.3 & 411.1 \\
\hline IV:11 & Teens & $\mathrm{F}$ & $\mathrm{N} / \mathrm{D}$ & No & Yes & $<0.5$ & 235.4 \\
\hline IV:12 & Teens & $\mathrm{F}$ & $\mathrm{N} / \mathrm{D}$ & No & Yes & $<0.5$ & 257.0 \\
\hline IV:13 & $20 s$ & $M$ & 165 & No & Yes & $<0.5$ & 268.7 \\
\hline IV:14 & $20 \mathrm{~s}$ & $M$ & 167 & No & Yes & $<0.5$ & 264.0 \\
\hline IV:15 & $20 \mathrm{~s}$ & $M$ & N/D & No & No & $<0.5$ & 178.4 \\
\hline IV:16 & $20 s$ & $M$ & $\mathrm{~N} / \mathrm{D}$ & No & No & $<0.5$ & 315.1 \\
\hline IV:17 & Teens & $M$ & N/D & No & Yes & 6.0 & 328.0 \\
\hline IV:18 & Teens & $M$ & N/D & No & Yes & $<0.5$ & 515.6 \\
\hline
\end{tabular}

IGF-1, insulin-like growth factor-1; M, male; F, female; N/D, not determined.

${ }^{\mathrm{a}} \mathrm{Age}$ is estimated in decades.

We used sex- and age-dependent reference ranges of IGF-1, which were established in a large group of patients (Brabant et al. 2003) and considered IGF-1 levels above +2 SDS as elevated (Schneider et al. 2008). With these criteria, all subjects have nonelevated levels of IGF-1, except IV:9. Besides having pronounced acromegalic features and elevated IGF-1 level, IV:9 also had an extremely high level of GH. She refused further diagnostics or treatment and died of hypopituitarism 2 years after her blood was collected.

We found a novel AIP frameshift mutation in exon 4 (c.500delC) (p.P167HfsX3) in all members with acromegalic features (II:3, III:6, III:9, IV:7, IV:8, and IV:9) as well as in 15 members without acromegalic phenotypes (III:2, III:3, III:7, III:10, III:12, IV:1, IV:3, IV:5, IV:10, IV:11, IV:12, IV:13, IV:14, IV:17, and IV:18), revealing incomplete penetrance of $A I P$ in this IFS family (Fig. 1). The penetrance of $A I P$ in this family was $28.6 \%(6 / 21)$. The frameshift mutation resulted from deletion of a cytosine, which changed from proline to histidine and caused an early stop codon at amino acid 170 (Fig. 2). This germline mutation may prevent the translation of the tetratricopeptide repeat (TPR) regions downstream and possibly creates a malfunctioning AIP protein.

It is known that somatotrope axis over-activity causes acromegalic features. However, in this study, we could not find strong or significant evidence of $\mathrm{GH}$ and/or IGF-1 levels associated with the features. This could be a mild form of acromegaly in this studied pedigree. Since the symptoms of acromegaly could not be clearly defined using the biochemical data in our study, we did not perform the linkage analysis based on biochemical data. Instead, linkage analysis was performed using the acromegalic features data, which could define the disease status according to the age of on-set ( $>20$ years old). The genome-wide scan results showed the highest LOD score, 2.2, located on 


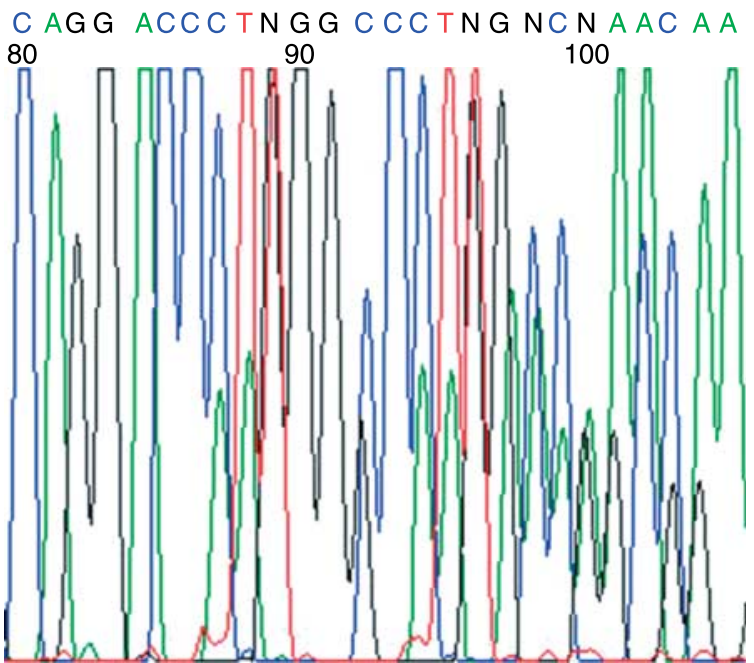

Figure 2 Sequence electropherogram showing the frameshift mutation c.500delC (P167fsX170) in exon 4 of the AIP gene of the Borneo IFS family.

19q13.41 (D19S571), which indicated suggestive evidence of linkage. In addition, we detected three weak linkages on chromosomes 3q28 (D3S1580), 8q12.1 (D8S285), and 21q22.13 (D21S1252) with LOD scores of 1.1, 1.8, and 1.4 respectively (Table 2 ). The whole-genome LOD plots are shown in Fig. 3.

\section{Discussion}

Germline mutations in the AIP gene were first discovered in PAP patients. The PAP phenotype, with a very low-penetrance susceptibility to somatotropinoma and prolactinoma, did not fit well in any of the known familial pituitary adenoma syndromes (Vierimaa et al. 2006). In FIPA, AIP mutations occur only in $50 \%$ of the IFS families and $15-30 \%$ of the entire FIPA cohort (Daly et al. 2007, Leontiou et al. 2008). In addition, AIP mutations are extremely rare in sporadic pituitary adenomas from patients of various countries (Barlier et al. 2007, Iwata et al. 2007, Raitila et al. 2007, Leontiou et al. 2008).

In our present study, we identified a novel AIP germline mutation, p.P167HfsX3, in a large IFS family from Borneo $(n=31)$. The newly identified $A I P$ germline mutation has a deletion of cytosine at nucleotide position 500, resulting in a premature stop codon at amino acid 170. It is similar to many known frameshift germline mutations of $A I P$, which are predicted to result in loss of translation of the TPR domains, which may disrupt the protein-protein interactions, resulting in malfunction of the AIP protein (Daly et al. 2007, Naves et al. 2007).

All members with acromegalic features $(n=6)$ have the germline mutation. Interestingly, a large fraction of members $(n=15)$ also carry the same mutation without showing any of the acromegalic features. Therefore, these asymptomatic carriers showed evidence of incomplete penetrance of $A I P$ in IFS. Penetrance is time-dependent and in this particular family, the penetrance was $28.6 \%$ at the time of sample collection. The low penetrance of AIP in PAP and FIPA families also suggests the existence of additional genes (Vierimaa et al. 2006, Daly et al. 2007, Naves et al. 2007). This indicates the mutation alone may not lead to the development of the symptoms of the disease. There is a high possibility that additional factors, either genetic or environmental, are assisting in or preventing the onset of IFS.

By using the established sex- and age-dependent reference ranges of IGF-1, it is known that healthy subjects can also have hormone levels outside of the normal range. Elevated IGF-1 levels are therefore not necessarily indicative of pathological acromegaly. Even with elevated IFG-1, it is not clear whether these patients will develop the clinical symptoms of acromegaly (Schneider et al. 2008). Therefore, IGF-1 values do not give a clear-cut clinical phenotype and we did not use it for linkage analysis. To identify the modifier genes/loci, the clinical phenotype has to be clearly defined and in some cases, it can be difficult to do so (Genin et al. 2008). In our study, subjects $>20$ years old should have their acromegalic features defined since IFS has a much younger age at onset compared with sporadic acromegaly (Soares \& Frohman 2004, Beckers \& Daly 2007). Thus, AIP mutants with the presence or absence of acromegaly feature were used in the linkage analysis to identify the modifier genes related to this phenotype. Although no

Table 2 Modifier regions of acromegaly features for isolated familial somatotropinoma

\begin{tabular}{|c|c|c|c|c|}
\hline Chromosomal region & Region size (cM) & Flanking microsatellites & Microsatellite ${ }^{a}$ & LOD \\
\hline $3 q 26.31-q 28$ & 18.2 & D3S1565-D3S1601 & D3S1580 & 1.1 \\
\hline $8 q 12-q 21.3$ & 58.5 & D8S505-D8S270 & D8S285 & 1.8 \\
\hline $19 q 12-q 13.43$ & 25.1 & D19S414-D19S210 & D19S571 & 2.2 \\
\hline $21 \mathrm{q} 22.11-\mathrm{q} 22.3$ & 10.5 & D21S263-D21S266 & $\mathrm{D} 21 \mathrm{~S} 1252$ & 1.4 \\
\hline
\end{tabular}

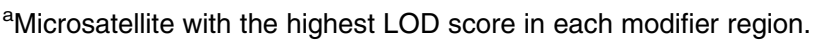




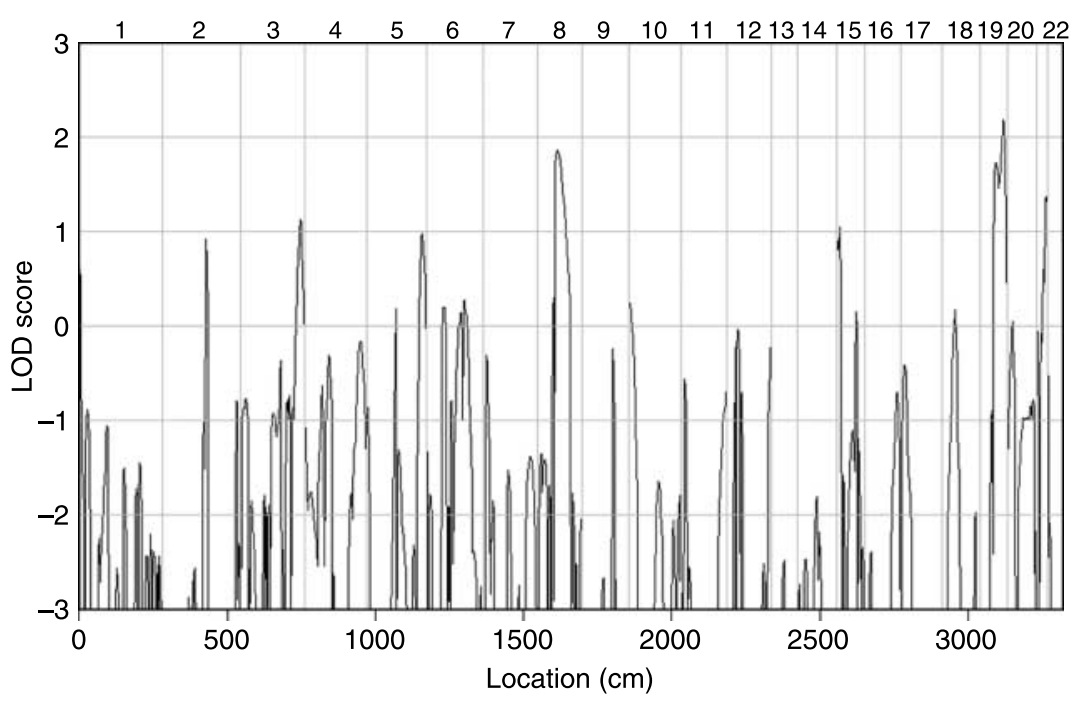

Figure 3 Multipoint nonparametric scores of the genome-wide scan for the Borneo IFS family. The chromosome number is plotted on the upper $X$-axis and the LOD score on the $Y$-axis. Suggestive linkage $(L O D=2.2)$ is shown in 19q13.41.

significant evidence of linkage was found (LOD $>3$ ) in the genome-wide linkage analysis, one suggestive linkage at chromosome 19q13.41 with a LOD score of 2.2 was detected. The definition of suggestive linkage (LOD $>1.9$ ) is based on Lander \& Kruglyak (1995). We also detected three chromosomes, 3q28, 8q12.1, and $21 \mathrm{q} 22.13$, with weak linkage to the phenotype. These regions are different from previously known putative loci for somatotropinoma susceptibility found on chromosomes 2p16-12 and 13q14 (Gadelha et al. 2000, Donangelo et al. 2005). However, the genomewide scan results in PAP family members reported by Vierimaa et al. (2006) detected a significant LOD score of 3.08 at chromosome 8q. It is the same chromosomal region where our data showed a weak evidence of linkage $(\mathrm{LOD}=1.8$ at $8 \mathrm{q} 12.1)$ and may merit further investigation. At present, we are fine mapping all candidate regions in order to identify modifier genes. Since the development of acromegalic features is insidious, this hormonal disorder is often not recognized immediately. Therefore, it is important to identify genes related to acromegaly, so that patients can be treated promptly to reduce the risk of complications. Moreover, identifying the modifier genes may lead to better understanding of the variety of clinical phenotypes of AIP mutants.

In summary, we have identified a novel $A I P$ germline mutation in a large IFS family, although complete endocrine diagnosis and data could not be collected due to logistical and cultural reasons. We also confirmed that $A I P$ is an incomplete-penetrance hereditary gene conferring a predisposition to IFS. More importantly, this is the first genome-wide linkage analysis to detect modifier loci for acromegalic features in IFS. A suggestive linkage on chromosome $19 \mathrm{q} 13.41$ and three weak linkages on chromosomes $3 q 28,8 q 12.1$, and $21 \mathrm{q} 22.13$ were identified. We conclude that genes located at those regions, especially near $19 q 13.41$, may modify the severity of acromegalic features in IFS patients.

\section{Declaration of interest}

The authors declare no conflicts of interest that could perceive as prejudicing the impartiality of the research reported.

\section{Funding}

This research did not receive any specific grant from any funding agency in the public, commercial or not-for-profit sector.

\section{Author contribution statement}

S K Khoo and B T Teh designed research; R Pendek, J Menon and S-P Chan contributed samples; S K Khoo, D C Luccio-Camelo, T L Newton and A Massie performed research; S K Khoo, R Nickolov, D Cameron, and D Petillo analyzed data; and S K Khoo wrote the paper.

\section{Acknowledgements}

We thank all participating subjects for their cooperation and contribution. T L Newton was supported by the Frederik and Lena Meijer Student Internship Program. We thank the Van Andel Foundation for financial support. We also thank David Nadziejka and Vanessa Fogg for technical editing and Sabrina Noyes for her administrative support. 


\section{References}

Barlier A, Vanbellinghen JF, Daly AF, Silvy M, Jaffrain-Rea ML, Trouillas J, Tamagno G, Cazabat L, Bours V, Brue T et al. 2007 Mutations in the aryl hydrocarbon receptorinteracting protein gene are not highly prevalent among subjects with sporadic pituitary adenomas. Journal of Clinical Endocrinology and Metabolism 92 1952-1955.

Beckers A \& Daly AF 2007 The clinical, pathological, and genetic features of familial isolated pituitary adenomas. European Journal of Endocrinology 157 371-382.

Brabant G, von zur Muhlen A, Wuster C, Ranke MB, Kratzsch J, Kiess W, Ketelslegers JM, Wilhelmsen L, Hulthen L, Saller B et al. 2003 Serum insulin-like growth factor I reference values for an automated chemiluminescence immunoassay system: results from a multicenter study. Hormone Research 60 53-60.

Chandrasekharappa SC, Guru SC, Manickam P, Olufemi SE, Collins FS, Emmert-Buck MR, Debelenko LV, Zhuang Z, Lubensky IA, Liotta LA et al. 1997 Positional cloning of the gene for multiple endocrine neoplasia-type 1. Science 276 404-407.

Daly AF, Jaffrain-Rea ML, Ciccarelli A, Valdes-Socin H, Rohmer V, Tamburrano G, Borson-Chazot C, Estour B, Ciccarelli E, Brue T et al. 2006 a Clinical characterization of familial isolated pituitary adenomas. Journal of Clinical Endocrinology and Metabolism 91 3316-3323.

Daly AF, Rixhon M, Adam C, Dempegioti A, Tichomirowa MA \& Beckers A $2006 b$ High prevalence of pituitary adenomas: a cross-sectional study in the province of Liege, Belgium. Journal of Clinical Endocrinology and Metabolism 91 4769-4775.

Daly AF, Vanbellinghen JF, Khoo SK, Jaffrain-Rea ML, Naves LA, Guitelman MA, Murat A, Emy P, GimenezRoqueplo AP, Tamburrano G et al. 2007 Aryl hydrocarbon receptor-interacting protein gene mutations in familial isolated pituitary adenomas: analysis in 73 families. Journal of Clinical Endocrinology and Metabolism 92 1891-1896.

Donangelo I, Araujo PB, Antenuzi D, Farage M, Marcondes J, Filho PN \& Gadelha MR 2005 Tumor deletion mapping of chromosomal region $13 \mathrm{q} 14$ in 43 growth hormone secreting pituitary adenomas. Endocrine 28 131-136.

Gadelha MR, Une KN, Rohde K, Vaisman M, Kineman RD \& Frohman LA 2000 Isolated familial somatotropinomas: establishment of linkage to chromosome 11q13.111q13.3 and evidence for a potential second locus at chromosome 2p16-12. Journal of Clinical Endocrinology and Metabolism 85 707-714.

Genin E, Feingold J \& Clerget-Darpoux F 2008 Identifying modifier genes of mongenic disease: strategies and difficulties. Human Genetics 124 357-368.

Iwata T, Yamada S, Mizusawa N, Golam HM, Sano T \& Yoshimoto K 2007 The aryl hydrocarbon receptorinteracting protein gene is rarely mutated in sporadic $\mathrm{GH}-$ secreting adenomas. Clinical Endocrinology 66 499-502.
Kirschner LS, Carney JA, Pack SD, Taymans SE, Giatzakis C, Cho YS, Cho-Chung YS \& Stratakis CA 2000 Mutations of the gene encoding the protein kinase A type I-alpha regulatory subunit in patients with the Carney complex. Nature Genetics 26 89-92.

Kong A \& Cox NJ 1997 Allele-sharing models: LOD scores and accurate linkage tests. American Journal of Human Genetics 61 1179-1188.

Kruglyak L \& Lander ES 1998 Faster multipoint linkage analysis using Fourier transforms. Journal of Computational Biology 5 1-7.

Kruglyak L, Daly MJ, Reeve-Daly MP \& Lander ES 1996 Parametric and nonparametric linkage analysis: a unified multipoint approach. American Journal of Human Genetics 58 1347-1363.

Lander E \& Kruglyak L 1995 Genetic dissection of complex traits: guidelines for interpreting and reporting linkage results. Nature Genetics 11 241-247.

Leontiou CA, Gueorguiev M, van der Spuy J, Quinton R, Lolli F, Hassan S, Chahal HS, Igreja SC, Jordan S, Rowe J et al. 2008 The role of the aryl hydrocarbon receptorinteracting protein gene in familal and sporadic pituitary adenomas. Journal of Clinical Endocrinology and Metabolism 93 2390-2401.

Naves LA, Daly AF, Vanbellinghen JF, Casulari LA, Spilioti C, Magalhaes AV, Azevedo MF, Giacomini LA, Nascimento PP, Nunes RO et al. 2007 Variable pathological and clinical features of a large Brazilian family harboring a mutation in the aryl hydrocarbon receptor-interacting protein gene. European Journal of Endocrinology 157 383-391.

O'Connell JR \& Weeks DE 1998 PedCheck: a program for identification of genotype incompatibilities in linkage analysis. American Journal of Human Genetics 63 259-266.

Raitila A, Georgitsi M, Karhu A, Tuppurainen K, Makinen MJ, Birkenkamp-Demtroder K, Salmenkivi K, Orntoft TF, Arola J, Launonen V et al. 2007 No evidence of somatic aryl hydrocarbon receptor-interacting protein mutations in sporadic endocrine neoplasia. Endocrine-Related Cancer 14 901-906.

Schneider HJ, Sievers C, Saller B, Wittchen HU \& Stalla GK 2008 High prevalence of biochemical acromegaly in primary care patients with elevated IGF-1 levels. Clinical Endocrinology 69 432-435.

Soares BS \& Frohman LA 2004 Isolated familial somatotropinoma. Pituitary 7 95-101.

Toledo RA, Lourenco DM Jr, Liberman B, Cunha-Neto MB, Cavalcanti MG, Moyses CB, Toledo SP \& Dahia PL 2007 Germline mutation in the aryl hydrocarbon receptor-interacting protein gene in familial somatotropinoma. Journal of Clinical Endocrinology and Metabolism 92 1934-1937.

Vierimaa O, Georgitsi M, Lehtonen R, Vahteristo P, Kokko A, Raitila A, Tuppurainen K, Ebeling TM, Salmela PI, Paschke R et al. 2006 Pituitary adenoma predisposition caused by germline mutations in the AIP gene. Science 312 1228-1230. 